\title{
Using Land Cover Change to Predict Forest Degradation Pressure Points, Eastern Mau Forest, Kenya
}

\author{
Antony Oduya Ndubi \\ Food and Agriculture Organization of the United Nations (FAO) Somalia, Somali Water and Land \\ Information Management (SWALIM) Programme, P. O. BOX 30470 - 00100, Nairobi, Kenya
}

anoduya@yahoo.com

Keywords: Eastern Mau Forest, Land Cover, Classification, Pressure Points, Satellite Imagery.

\begin{abstract}
Land cover change in any ecosystem vary in space and time. The study analyzed spatialtemporal land cover change to predict forest degradation pressure points in Eastern Mau Forest Reserve. The study objectives were to determine types and amount of spatial-temporal land cover change; land cover change drivers and; forest resources use sustainability. The study used mixed sample survey design involving purposive sampling of spatial data and cluster sampling of forest resource use data. Primary data included ground control points, field validation data and forest resource use data. Secondary data included Landsat imagery, forest and administration boundaries and settlements data. Analysis was done for 1986-2014 period using Remote Sensing and Geographical Information System. The analysis techniques used included object based image segmentation and classification, accuracy assessment and land cover change detection. Land cover types in Eastern Mau Forest consisted of indigenous forest, shrubland, grassland, plantation forest, cultivated fields, bare ground and built-up area. The analysis results depicted that cultivated fields coverage increased from $1 \%$ to $47 \%$. Indigenous and plantation forests decreased from $43 \%$ to $36 \%$ and $34 \%$ to $7 \%$ respectively. Grassland and shrubland decreased from $16 \%$ to $8 \%$ and $6 \%$ to $2 \%$ respectively. Bare ground and built up area had a change of less than $1 \%$ each. Causes of pressure that lead to forest degradation included crop cultivation, settlement construction, livestock grazing, charcoal burning, firewood collection, logging, bee keeping and medicinal herbs extraction. Land cover change was more on the eastern side than on the western side. Indigenous and plantation forests were likely to disappear if cropland and built up area expansions were to remain unchecked. The study recommendations were: resettlement activities be eliminated in the Eastern Mau Forest; excision of forest land for crop cultivation should be discouraged; and scientific research should be carried out on sustainable plantation forest activities.
\end{abstract}

\section{Introduction}

Land cover change in forest ecosystems leads to forest degradation that has an effect of lowering levels of carbon sequestration thereby increasing carbon emissions into the atmosphere which consequently contributes to climate change. The land cover change in Eastern Mau Forest Reserve that mostly results from sharing of benefits from forest resources leads to massive forest loss. Little information is available on the amount of forest loss and the source of pressure that causes the loss. This requires appropriate tools and approaches like Remote Sensing and Geographical Information Systems to determine the extent of forest destruction and the likely pressure points.

Eastern Mau Forest Reserve forms part of Mau forests complex which is one of the five Kenyan water towers. It is considered to be the most important watershed in Kenya because of its economic, social and environmental contribution to the country. The forest has for a long time been under increasing threat of degradation resulting from encroachments and illegal forest exploitation due to conflicting interests from different users of forest resources. This results in massive land cover change within the forest. The problem emanating from competing land uses and its impact on natural environment is one that has been felt in many parts of the world. Mostly, the impact has been degradation of the natural environment. Destruction of forests is leading to a serious water 
crisis as perennial rivers are becoming seasonal and downstream flooding of rivers is increasing. There is increasing loss of biodiversity as well as increase in carbon dioxide emissions as a result of forest cover loss. Poor soil and water resources conservation in deforested land leads to soil erosion and decreasing crop yields in areas of high agricultural potential. According to one of the Kenya Forests Working Group reports [1], the Mau forests complex decreased in area by approximately 34,000 hectares, translating to $9 \%$ forest loss, from 1964 to 2000 . This decrease forms part of the estimates by Food and Agriculture Organization of the United Nations which puts the rate of deforestation of natural forests in developing countries between 1990 and 1995 at 13.7 hectares per annum [2]. Rapid population growth and migrations to areas deemed to be favourable for agriculture are a concern in tropical regions worldwide due to the resultant rapid deforestation and ecosystem defragmentation [3].

The government of Kenya gazetted a policy on forest excision which created tea plantation zones around natural forest conservation areas in 1986 aimed at preventing forest encroachment [4]. The same government gazetted another policy in the same year on moving communities staying in the forest and resettling them outside of gazetted forests [5]. The study looked at the effects of the two policies on conservation of natural forest and found that there was nothing to show that they helped to reduce forest degradation. There is, therefore, need to find ways of implementing such policies and try to find out the likely impacts of the policies. It is also important to educate the citizens on the importance of such environmental conservation policies.

Little information is available on spatial and temporal extent of land cover change and the likely points of pressure that cause the change. It is important that appropriate tools and approaches like Remote Sensing and Geographical Information Systems (GIS) are used to make information available for decision making and planning [6]. There is an enormous benefit gained by monitoring land cover changes as it provides information regarding areas that have little or no access as well as enable more efficient and cost effective land cover mapping [7]. The main goal of this study was to determine the likely locations of the drivers of land cover change in the area of study by identifying the changes occurring in different land cover types and the human activities causing those changes.

\section{Area of Study}

Eastern Mau Forest Reserve is located in Molo Sub-county of Nakuru County in the South Eastern part of Rift Valley Region of Kenya. It lies between 35.690 and 36.100 East and 0.280 and 0.680 South (Fig. 1). It is bordered by Naivasha Sub-county to the South, Narok and Bomet Counties to the West, Nyandarua and Laikipia Counties to the East, and Kericho and Baringo Counties to the North. It forms part of the larger Mau Forests Complex that is the largest closedcanopy montane forest ecosystem in East Africa. It can be classified as an equatorial forest based on its location but it is taken as montane forest because of the altitude. The Mau complex has an altitude range of between $1,800 \mathrm{~m}$ and $3,000 \mathrm{~m}$ above sea level [8]. It has 22 forest blocks and covers approximately 416,542 ha with the Eastern Mau covering a spatial area of about 65,900 ha [9]. The total Kenya's forest cover is approximately 980,000 ha [10]. 


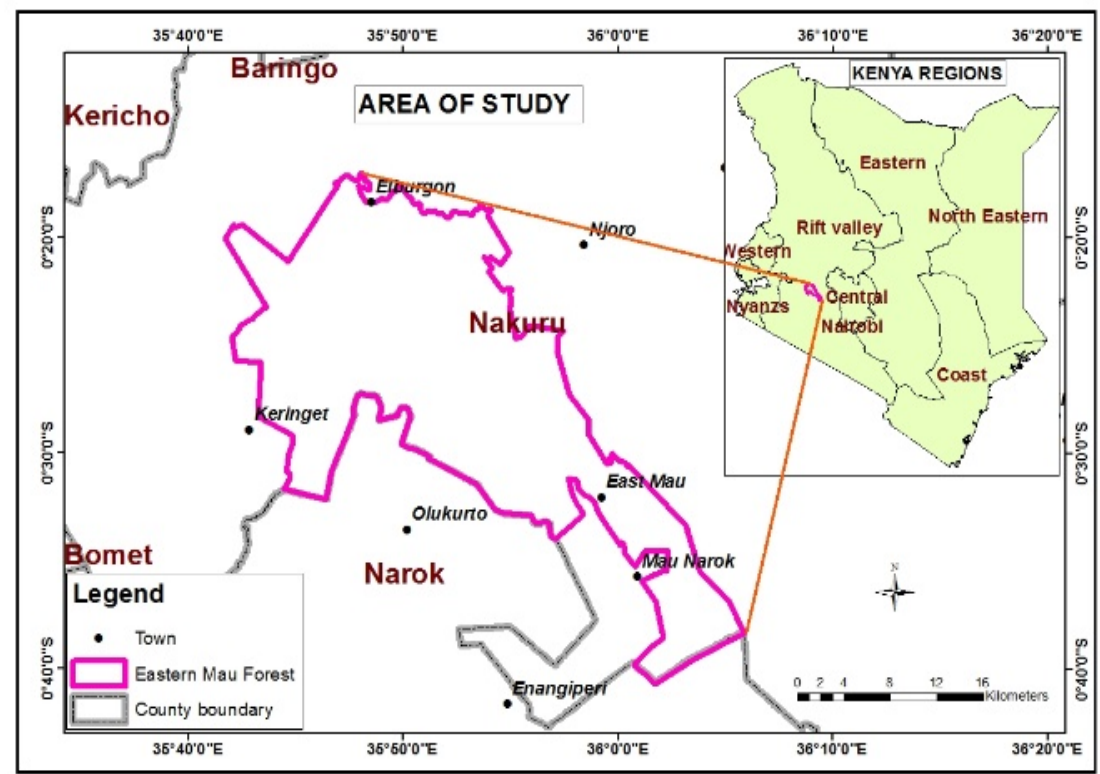

Figure 1. Location of Eastern Mau Forest

The area is mainly composed of quaternary and tertiary volcanic deposits [11]. The quaternary deposits include pyroclastics and sediments. Tertiary deposits include black ashes and welded tuffs [12]. It has both temperate and equatorial climatic characteristics due to relatively high altitudes and proximity to the equator. Eastern Mau Forest Reserve is drained by many rivers and these include Njoro, Makalia, Enderit, Naishi, Nessuit, Rongai, Elburgon, Mariashoni and Kiptunga rivers.

\section{Data and Methods}

\subsection{Data}

The data used in this study were of primary and secondary data types where primary data were on land cover types and forest resource use. Primary data on land cover types were collected for land cover validation of the preliminary satellite image interpretation. Forest resource use data were collected from 32 stakeholder interviews on the basis of forest resource use activities for identification of drivers of land cover change. The 32 stakeholders were identified from different households within $5 \mathrm{~km}$ buffer area around the gazetted forest boundary. Secondary data were acquired from already existing datasets covering the area of study and relevant to the study. These secondary data included spatial data in the form of Landsat imageries of $30 \mathrm{~m}$ spatial resolution from TM (1986 and 1995), ETM+ (2003) and OLI (2014) sensors (Table 1) provided by the National Aeronautics and Space Administration (NASA). The Landsat data were selected on the basis of amount of cloudy cover and season of the year. The selected images were those with less than 10 per cent cloudy cover, within January-February season and close to 10 year time interval between them. These images were used to generate land cover types and land cover change information.

Table 1. Landsat imagery characteristics

\begin{tabular}{|l|r|r|r|}
\hline \multirow{2}{*}{ Sensor } & \multicolumn{3}{|c|}{ Characteristics } \\
\cline { 2 - 4 } & Spatial resolution & Spectral resolution & Temporal resolution \\
\hline TM & 30 metres & 7 bands & 16 days \\
\hline ETM+ & 30 metres & 8 bands & 16 days \\
\hline OLI & 30 metres & 11 bands & 16 days \\
\hline
\end{tabular}

Other secondary data were in form of Kenya forest boundaries from Kenya Forest Service, population data from Kenya National Bureau of Statistics, and 1:50,000 topographic maps, sublocation and county boundary shapefiles, Kenya rivers shapefile and settlement shapefile from 
Survey of Kenya. Kenya forest boundaries data was for Eastern Mau Forest boundary delimitation and reconciling the observed forest boundaries with the legal forest boundaries. Kenya population data of 1989, 1999 and 2009 was used for identification of human-forest interactions. The 1:50,000 topographic maps of Keringeti, Njoro, Olenguruone, Mau Narok and Ol Doinyo Opuru were used for Eastern Mau Forest location while the sub-location and county boundary shapefiles were for administrative units identification. Kenya rivers shapefile and the settlement shapefile were selected on the basis of spatial representation of Eastern Mau.

\subsection{Methods}

Landsat images were identified based on a predefined grid composed of array of paths and rows. The Eastern Mau Forest boundary vector file was uploaded on United States Geological Survey (USGS) website and overlaid on Landsat satellite imagery grid to identify the images covering the area of study. Eastern Mau Forest is covered by path 169 and row 60 of the Landsat grid (Fig. 2). Landsat images were assessed and screened for suitability in terms of cloud free, seasonality and time interval between 1984 and 2014. Based on the screening and assessment that was done images that had less than $10 \%$ cloud cover, captured in the same season (JanuaryFebruary) and within close to 10 year time interval were identified, selected and downloaded. The downloaded images were of January 1986, January 1995, February 2003 and January 2014.

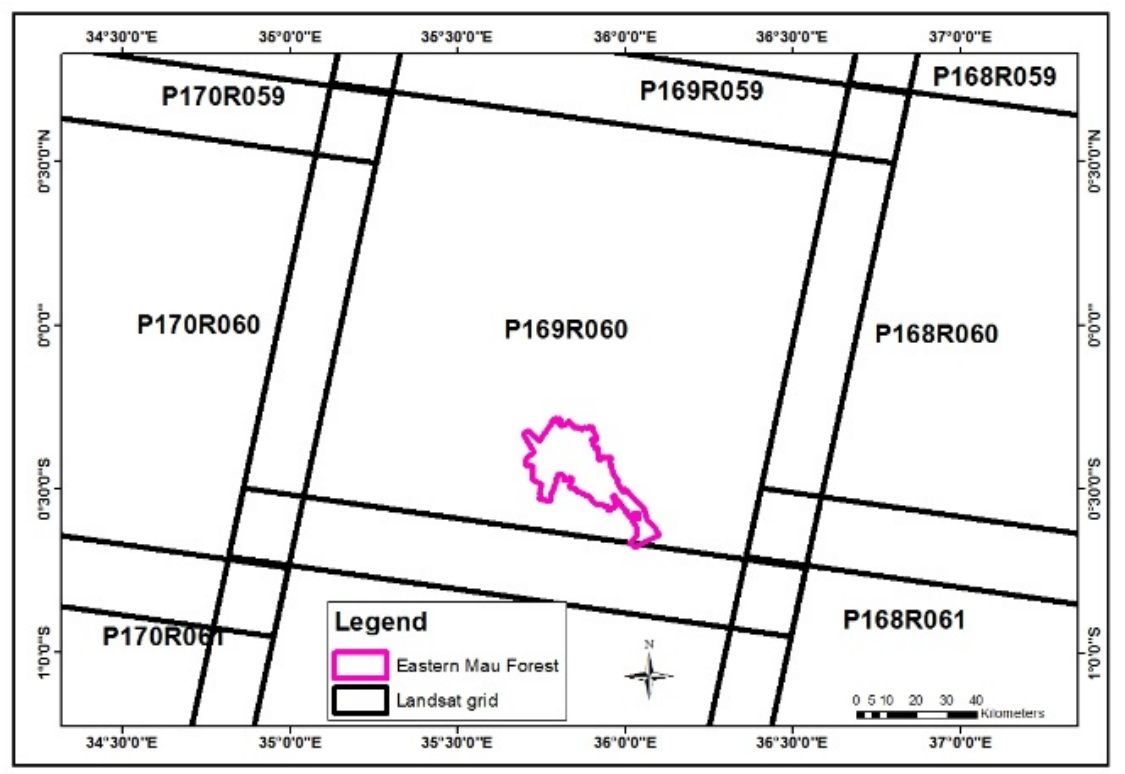

Figure 2. Landsat grid covering Eastern Mau Forest

The downloaded images were radiometrically and geometrically corrected before they were processed. Radiometric correction was done to remove the distortions that occur when electromagnetic radiations interact with atmospheric materials. This correction was carried out in ENVI 5.1 software using radiance calibration tool. Geometric correction was carried out to remove the shift that appears between images as a result of different sensor flight heights for images of the same place captured at different times. This correction was done through image geo-rectification using ArcGIS 10.3 software. Six distinct features were identified on all images and their corresponding positions on the ground located. The geographic coordinates of the six points were recorded using a handheld GPS unit at the exact ground positions. The recorded coordinates were used in the geo-rectification process.

The corrected images were processed using ArcGIS 10.3 software. To be able to clearly distinguish different land cover types different image bands were combined to give colour composite images and then clipped based on Eastern Mau Forest boundary (Figs. 3, 4, 5 and 6). The combined image bands were green, red and near infra-red bands giving colour infra-red composite image for vegetation analysis. These bands were 2, 3 and 4 for TM and ETM+ images, and 3, 4 and 5 for OLI image. 


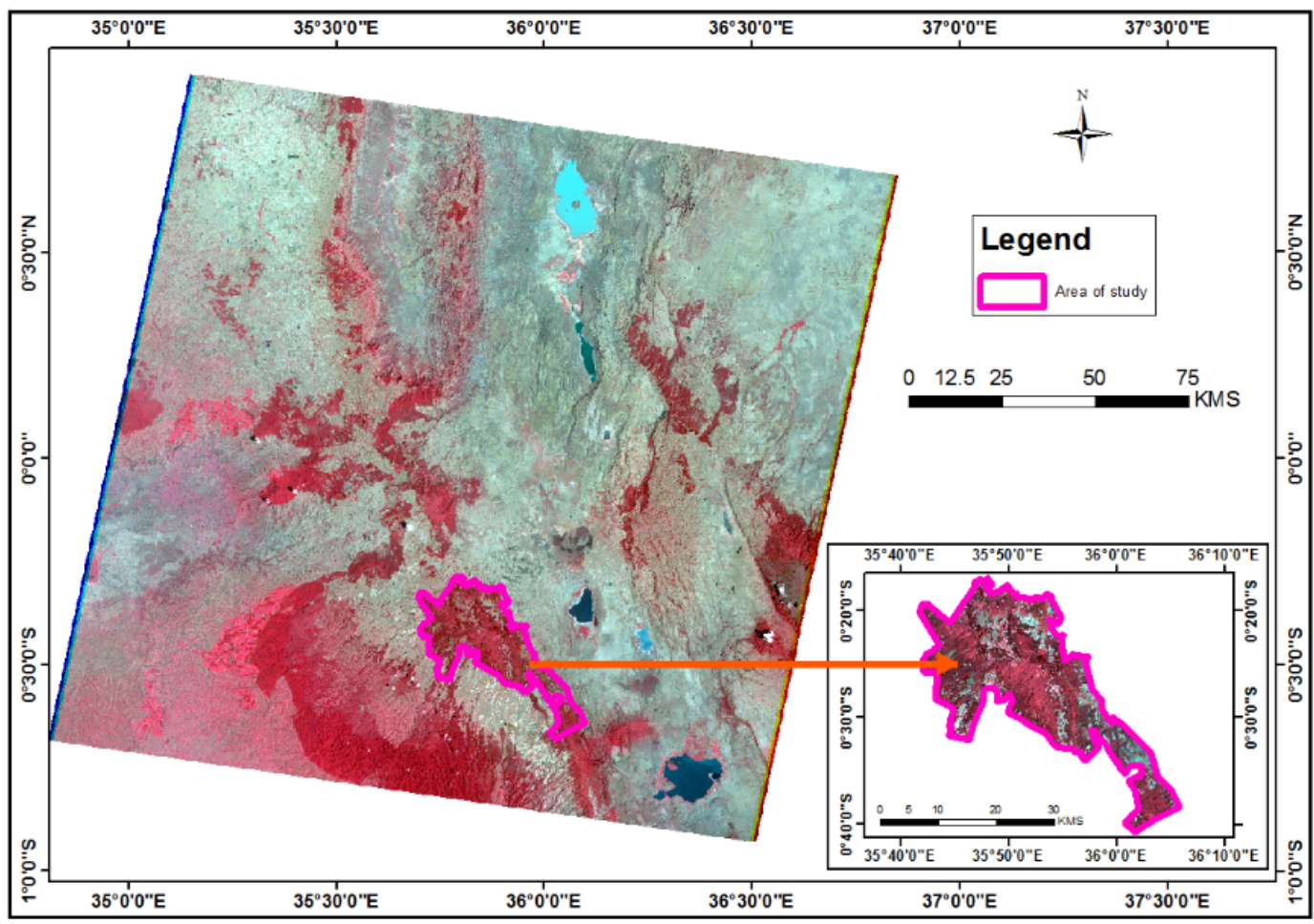

Figure 3. 1986 full composite and clipped images

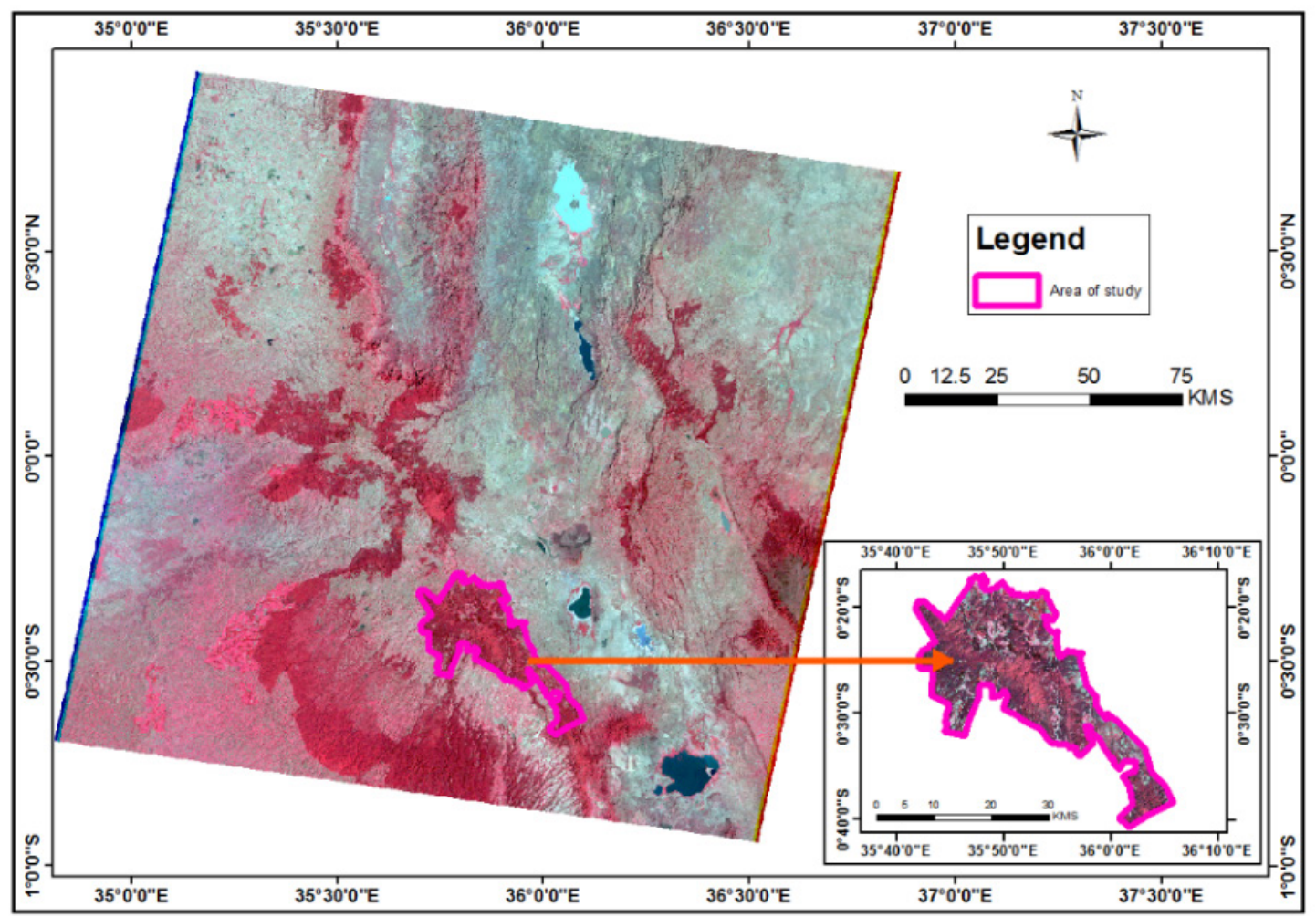

Figure 4. 1995 full composite and clipped images 


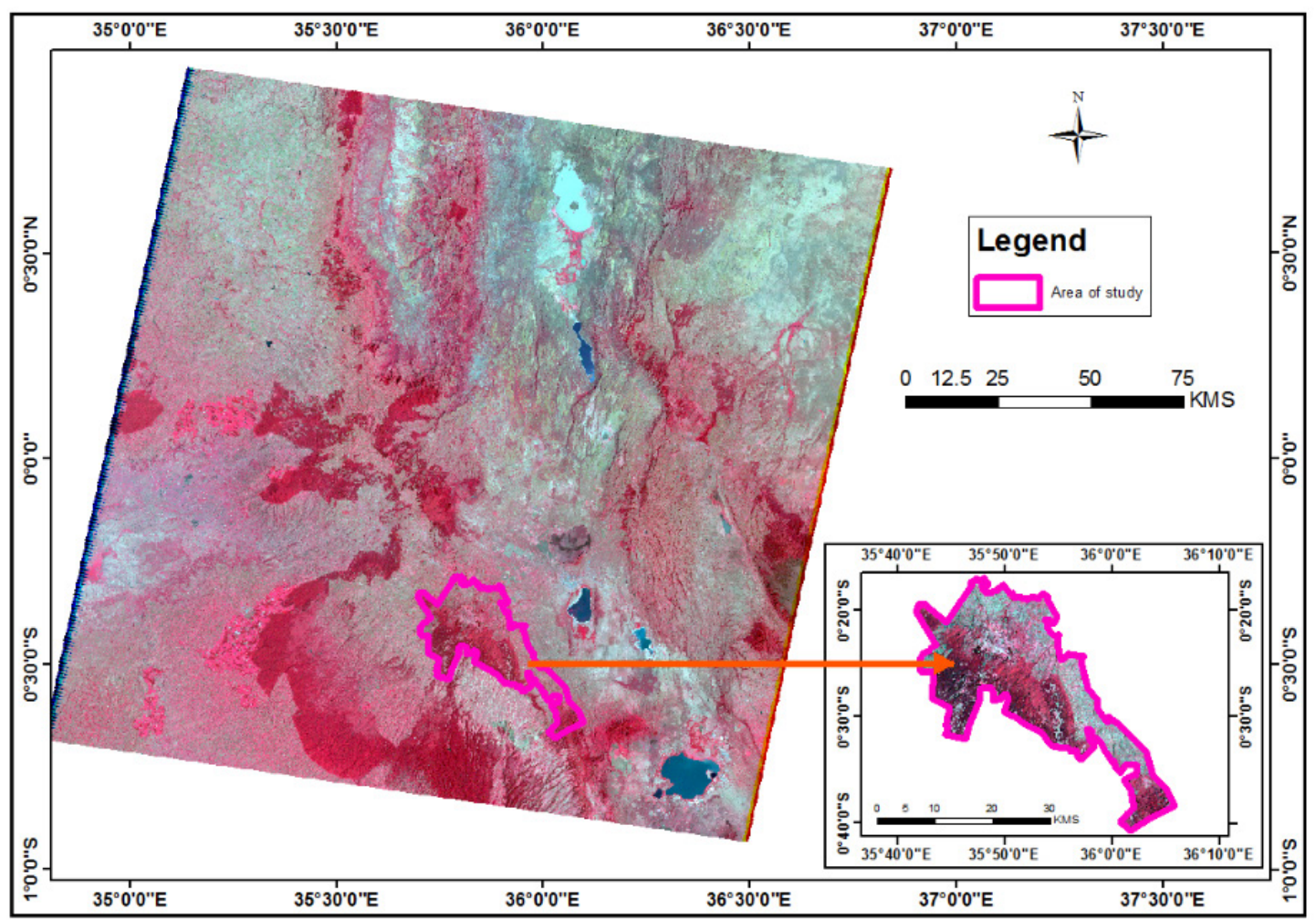

Figure 5. 2003 full composite and clipped images

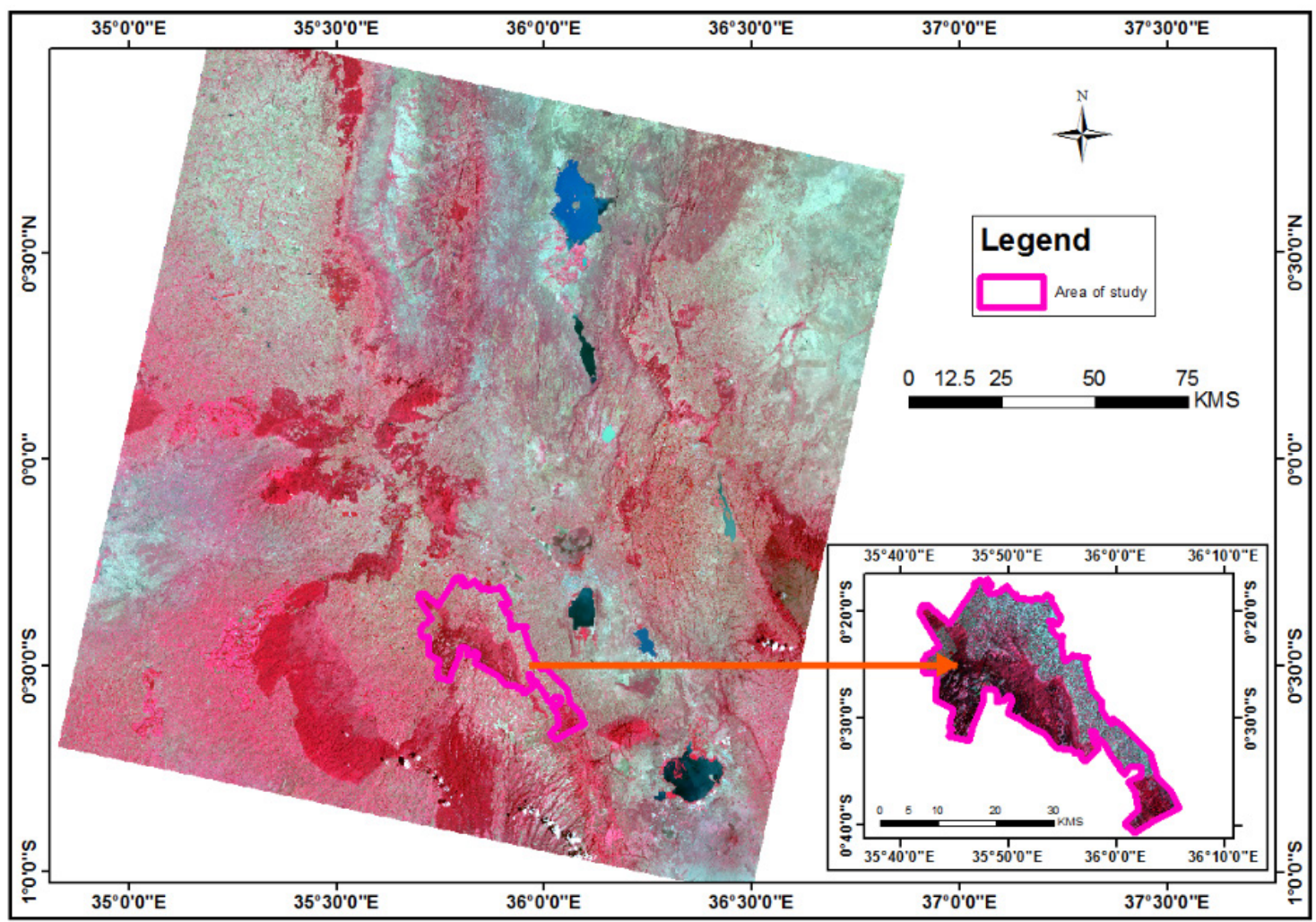

Figure 6. 2014 full composite and clipped images

The clipped satellite images were classified for land cover types generation based on object based classification methodology by segmentation of polygons around spatially homogeneous areas of the images. This methodology is relatively new as compared to pixel based image classification [13]. Field validation was carried out and points of different land cover types visited. Random points were generated on the satellite imagery within the forest boundary (Fig. 7) and uploaded in 
the hand held GPS receiver. The corresponding ground points were navigated to for observation and identification of different land cover types and the competing uses. Relevant stakeholders were interviewed to get additional information on the competing land uses. Observed land cover types were used to validate and make changes where necessary on the classes interpreted from satellite images (Fig. 8). The overall accuracy of the classified images was $99.999 \%$ for $1986,99.995 \%$ for 1995, 99.99\% for 2003 and $99.62 \%$ for 2014. The Kappa index of agreement of the classified images was 1 for 1986, 0.9999 for 1995, 0.9998 for 2003 and 0.9941 for 2014. The producer's and user's accuracies were different for different land cover types as shown in the results. The changes in land cover between different years were computed by change detection in IDRISI Selva software using cross-tabulation analysis by Land Change Modeler tool.

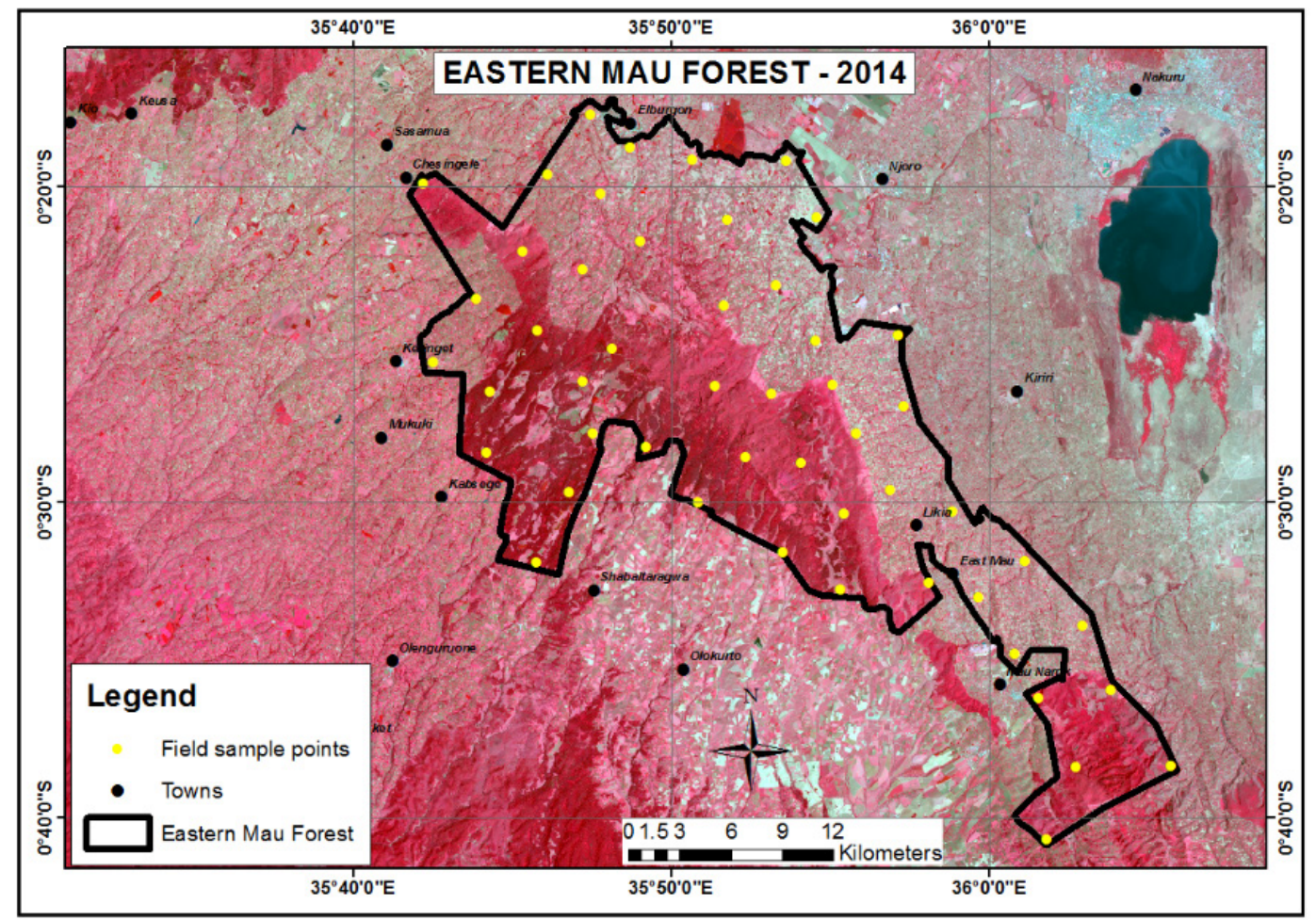

Figure 7. Field points overlaid on Landsat image

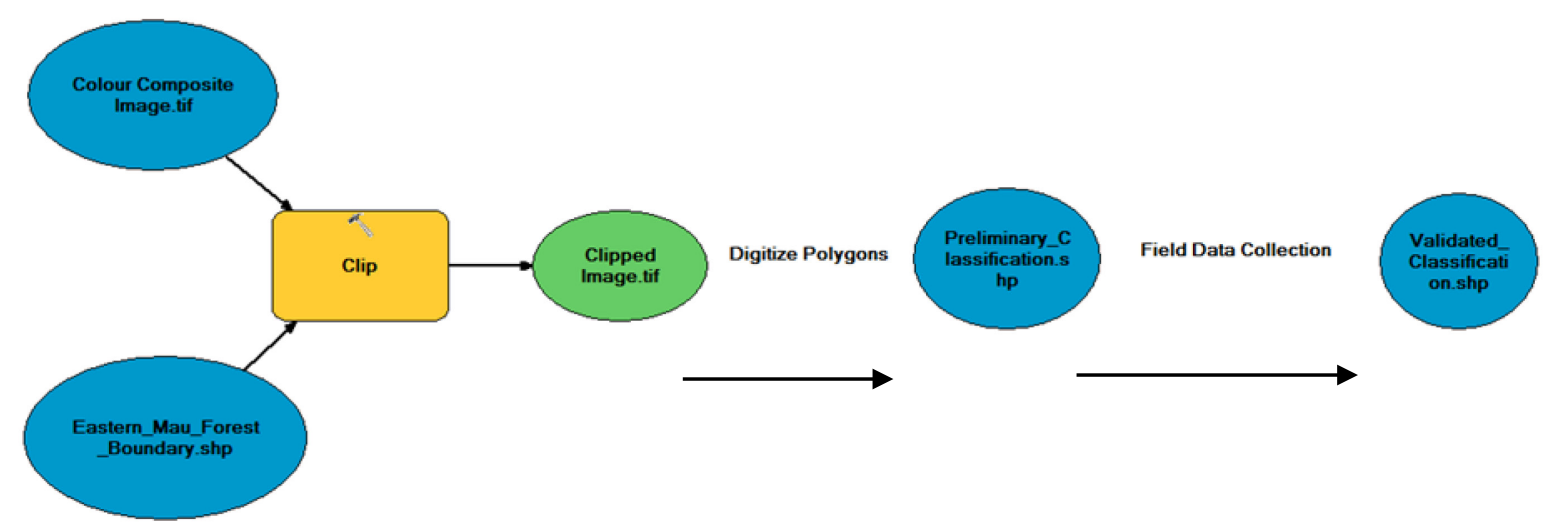

Figure 8. GIS model used in image analysis and field data collection 


\section{Results and Discussion}

\subsection{Accuracy Assessment Results}

Accuracy assessment was carried out to determine how accurate land cover classification from the satellite images was done. This was important in determining the level to which the classification agrees with the reality on the ground. This was achieved by getting field validated data and comparing it to the preliminary interpretation data using an error matrix that compared land cover classes on category by category basis. Four different statistics categories were computed based on the error matrix in the accuracy assessment that was carried out. The first two were categories were producer's accuracy and user's accuracy for analysing specific land cover types. The other two were overall accuracy and Kappa index of agreement (Tables 2, 3, 4 and 5). Overall accuracy gave the average accuracy obtained in the image interpretation and classification. Producer's and user's accuracies gave the level of accuracy in classifying different land cover types in terms of error of omission and error of commission respectively. Kappa index of agreement gave the difference between actual agreement in classification and the agreement expected by chance [14].

Table 2. Error matrix for 1986 land cover classification

\begin{tabular}{|c|c|c|c|c|c|c|c|c|c|c|c|}
\hline & \multicolumn{11}{|c|}{ Field Validated Data } \\
\hline \multirow{11}{*}{ 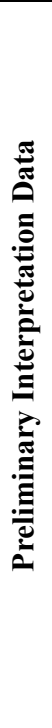 } & $\begin{array}{l}\text { Land } \\
\text { Cover } \\
\text { Classes }\end{array}$ & Grassland & Shrubland & $\begin{array}{c}\text { Cultivated } \\
\text { fields }\end{array}$ & $\begin{array}{c}\text { Indigenous } \\
\text { forest }\end{array}$ & $\begin{array}{c}\text { Plantation } \\
\text { forest }\end{array}$ & $\begin{array}{l}\text { Bare } \\
\text { ground }\end{array}$ & $\begin{array}{l}\text { Built } \\
\text { up } \\
\text { area }\end{array}$ & $\begin{array}{l}\text { Total } \\
\text { Pixels }\end{array}$ & $\begin{array}{c}\text { Producer's } \\
\text { Accuracy } \\
(\%)\end{array}$ & $\begin{array}{c}\text { User's } \\
\text { Accuracy } \\
(\%)\end{array}$ \\
\hline & Grassland & 119388 & 0 & 0 & 0 & \begin{tabular}{l|l}
0 \\
\end{tabular} & 0 & 0 & 119396 & 100 & 99.993 \\
\hline & Shrubland & 0 & 39986 & 0 & 0 & \begin{tabular}{l|l}
0 \\
\end{tabular} & 0 & 0 & 39986 & 100 & 100 \\
\hline & $\begin{array}{l}\text { Cultivated } \\
\text { fields }\end{array}$ & 0 & 0 & 9374 & 0 & 0 & 0 & 0 & 9374 & 100 & 100 \\
\hline & $\begin{array}{l}\text { Indigenous } \\
\text { forest }\end{array}$ & 0 & 0 & 0 & 317490 & 0 & 0 & 0 & 317491 & 100 & 99.999 \\
\hline & $\begin{array}{l}\text { Plantation } \\
\text { forest }\end{array}$ & 0 & 0 & 0 & 0 & 245552 & 0 & 0 & 245552 & 99.999 & 100 \\
\hline & $\begin{array}{l}\text { Bare } \\
\text { ground }\end{array}$ & 0 & 0 & 0 & 0 & 0 & 97 & 0 & 97 & 100 & 100 \\
\hline & $\begin{array}{l}\text { Built up } \\
\text { area }\end{array}$ & 0 & 0 & 0 & 0 & 0 & 0 & 204 & 204 & 99.226 & 100 \\
\hline & $\begin{array}{l}\text { Total } \\
\text { Pixels } \\
\end{array}$ & 119388 & 39986 & 9374 & 317490 & 245553 & 97 & 212 & 732100 & & \\
\hline & Overall Cl & ification & Accuracy $=$ & $=(732,091 / 7$ & $32,100) \times 100$ & $=99.999 \%$ & & & & & \\
\hline & Overa & St & $(0.999$ & $33) /(1$ & 3) $=1$ & & & & & & \\
\hline
\end{tabular}

Table 3. Error matrix for 1995 land cover classification

\begin{tabular}{|c|c|c|c|c|c|c|c|c|c|c|c|}
\hline & \multicolumn{11}{|c|}{ Field Validated Data } \\
\hline \multirow{11}{*}{ 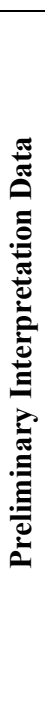 } & $\begin{array}{c}\text { Land } \\
\text { Cover } \\
\text { Classes }\end{array}$ & Grassland & Shrubland & $\begin{array}{c}\text { Cultivated } \\
\text { fields }\end{array}$ & $\begin{array}{c}\text { Indigenous } \\
\text { forest }\end{array}$ & $\begin{array}{c}\text { Plantation } \\
\text { forest }\end{array}$ & $\begin{array}{c}\text { Bare } \\
\text { ground }\end{array}$ & $\begin{array}{c}\text { Built up } \\
\text { area }\end{array}$ & $\begin{array}{c}\text { Total } \\
\text { Pixels }\end{array}$ & \begin{tabular}{|c|}
$\begin{array}{c}\text { Producer's } \\
\text { Accuracy } \\
(\%)\end{array}$ \\
\end{tabular} & $\begin{array}{c}\text { User's } \\
\text { Accuracy } \\
(\%)\end{array}$ \\
\hline & Grassland & 107839 & 0 & 0 & 0 & 0 & 0 & 0 & 107861 & 100 & 99.98 \\
\hline & Shrubland & 0 & 26573 & 0 & 0 & 0 & 0 & 0 & 26573 & 100 & 100 \\
\hline & $\begin{array}{l}\text { Cultivated } \\
\text { fields }\end{array}$ & 0 & 0 & 18123 & 0 & 0 & 0 & 0 & 18137 & 100 & 99.92 \\
\hline & $\begin{array}{l}\text { Indigenous } \\
\text { forest }\end{array}$ & 0 & 0 & 0 & 333934 & 0 & 0 & 0 & 333934 & 100 & 100 \\
\hline & $\begin{array}{l}\text { Plantation } \\
\text { forest }\end{array}$ & 0 & 0 & 0 & 0 & 245385 & 0 & 0 & 245385 & 100 & 100 \\
\hline & \begin{tabular}{|l}
$\begin{array}{l}\text { Bare } \\
\text { ground }\end{array}$ \\
\end{tabular} & 0 & 0 & 0 & 0 & 0 & 97 & 0 & 97 & 100 & 100 \\
\hline & $\begin{array}{l}\text { Built up } \\
\text { area }\end{array}$ & 0 & 0 & 0 & 0 & 0 & 0 & 113 & 113 & 75.84 & 100 \\
\hline & $\begin{array}{l}\text { Total } \\
\text { Pixels }\end{array}$ & 107839 & 26573 & 18123 & 333934 & 245385 & 97 & 149 & 732100 & & \\
\hline & \multicolumn{11}{|c|}{ Overall Classification Accuracy $=(732,064 / 732,100) \times 100=99.995 \%$} \\
\hline & \multicolumn{11}{|c|}{ Overall Kappa Statistic $=(0.99995-0.34) /(1-0.34)=0.9999$} \\
\hline
\end{tabular}


Table 4. Error matrix for 2003 land cover classification

\begin{tabular}{|c|c|c|c|c|c|c|c|c|c|c|c|}
\hline & \multicolumn{11}{|c|}{ Field Validated Data } \\
\hline \multirow{11}{*}{ 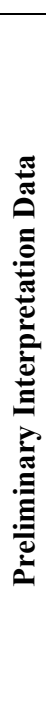 } & $\begin{array}{c}\text { Land } \\
\text { Cover } \\
\text { Classes }\end{array}$ & Grassland & Shrubland & $\begin{array}{c}\text { Cultivated } \\
\text { fields }\end{array}$ & $\begin{array}{c}\text { Indigenous } \\
\text { forest }\end{array}$ & \begin{tabular}{|c|}
$\begin{array}{c}\text { Plantation } \\
\text { forest }\end{array}$ \\
\end{tabular} & $\begin{array}{c}\text { Bare } \\
\text { ground }\end{array}$ & $\begin{array}{c}\text { Built } \\
\text { up area }\end{array}$ & $\begin{array}{c}\text { Total } \\
\text { Pixels }\end{array}$ & $\begin{array}{c}\text { Producer's } \\
\text { Accuracy } \\
(\%)\end{array}$ & \begin{tabular}{|c|} 
User's \\
Accuracy \\
(\%)
\end{tabular} \\
\hline & Grassland & 64435 & 0 & 0 & 0 & 0 & 0 & 25 & 64460 & 100 & 99.96 \\
\hline & Shrubland & 0 & 27086 & 0 & 0 & 0 & 0 & 0 & 27086 & 100 & 100 \\
\hline & $\begin{array}{l}\text { Cultivated } \\
\text { fields }\end{array}$ & 0 & 0 & 278543 & 0 & 0 & 0 & 88 & 278631 & 100 & 99.97 \\
\hline & $\begin{array}{l}\text { Indigenous } \\
\text { forest }\end{array}$ & 0 & 0 & 0 & 281415 & 0 & 0 & 0 & 281415 & 100 & 100 \\
\hline & $\begin{array}{l}\text { Plantation } \\
\text { forest }\end{array}$ & 0 & 0 & 0 & 0 & 80179 & 0 & 0 & 80179 & 100 & 100 \\
\hline & \begin{tabular}{|l|} 
Bare \\
ground
\end{tabular} & 0 & 0 & 0 & 0 & 0 & 59 & 0 & 59 & 100 & 100 \\
\hline & $\begin{array}{l}\text { Built up } \\
\text { area }\end{array}$ & 0 & 0 & 0 & 0 & 0 & 0 & 270 & 270 & 70.50 & 100 \\
\hline & \begin{tabular}{|l|} 
Total \\
Pixels
\end{tabular} & 64435 & 27086 & 278543 & 281415 & 80179 & 59 & 383 & 732100 & & \\
\hline & \multicolumn{11}{|c|}{ Overall Classification Accuracy $=(731987 / 732,100) \times 100=99.99 \%$} \\
\hline & \multicolumn{11}{|c|}{ Overall Kappa Statistic $=(0.99985-0.31) /(1-0.31)=0.9998$} \\
\hline
\end{tabular}

Table 5. Error matrix for 2014 land cover classification

\begin{tabular}{|c|c|c|c|c|c|c|c|c|c|c|c|}
\hline & \multicolumn{11}{|c|}{ Field Validated Data } \\
\hline \multirow{10}{*}{ 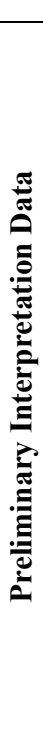 } & $\begin{array}{l}\text { Land } \\
\text { Cover } \\
\text { Classes }\end{array}$ & Grassland & Shrubland & $\begin{array}{c}\text { Cultivated } \\
\text { fields }\end{array}$ & $\begin{array}{l}\text { Indigenous } \\
\text { forest }\end{array}$ & $\begin{array}{c}\text { Plantation } \\
\text { forest }\end{array}$ & $\begin{array}{l}\text { Bare } \\
\text { ground }\end{array}$ & $\begin{array}{c}\text { Built } \\
\text { up } \\
\text { area }\end{array}$ & $\begin{array}{l}\text { Total } \\
\text { Pixels }\end{array}$ & $\begin{array}{c}\text { Producer's } \\
\text { Accuracy } \\
\text { (\%) }\end{array}$ & $\begin{array}{c}\text { User's } \\
\text { Accuracy } \\
\text { (\%) }\end{array}$ \\
\hline & Grassland & 61581 & 0 & 0 & 0 & 0 & 0 & 0 & 61581 & 99.70 & 100 \\
\hline & Shrubland & 0 & 13933 & 0 & 0 & 1578 & 0 & 0 & 15511 & 100 & 89.83 \\
\hline & $\begin{array}{l}\text { Cultivated } \\
\text { fields }\end{array}$ & 183 & 0 & 342674 & 0 & 11 & 0 & 150 & 343018 & 100 & 99.90 \\
\hline & $\begin{array}{l}\text { Indigenous } \\
\text { forest }\end{array}$ & 0 & 0 & 0 & 261238 & 843 & 0 & 0 & 262081 & 100 & 99.68 \\
\hline & $\begin{array}{l}\text { Plantation } \\
\text { forest }\end{array}$ & 0 & 0 & 0 & 0 & 49210 & 0 & 0 & 49210 & 95.29 & 100 \\
\hline & $\begin{array}{l}\text { Bare } \\
\text { ground }\end{array}$ & 0 & 0 & 0 & 0 & 0 & 34 & 0 & 34 & 100 & 100 \\
\hline & $\begin{array}{l}\text { Built up } \\
\text { area }\end{array}$ & 0 & 0 & 0 & 0 & 0 & 0 & 665 & 665 & 81.60 & 100 \\
\hline & $\begin{array}{l}\text { Total } \\
\text { Pixels }\end{array}$ & 61764 & 13933 & 342674 & 261238 & 51642 & 34 & 815 & 732100 & & \\
\hline & \begin{tabular}{|l|} 
Overal \\
Overal
\end{tabular} & ification & $\begin{array}{l}\text { cy }= \\
962\end{array}$ & $\frac{29335 / 732}{36) /(1-0.36}$ & $\begin{array}{l}, 100) \times 100= \\
0.9941\end{array}$ & & & & & & \\
\hline
\end{tabular}

\subsection{Land Cover Classification Results}

Eastern Mau Forest land cover was classified into seven land cover classes based on Landsat satellite imagery analysis and field observation and validation. These land cover classes included indigenous forest, plantation forest, cropland, grassland, shrubland, built-up area and bare ground with indigenous forest as the dominant land cover type. It is evident from the observations and land cover classification made that forest land cover changes that occur in Eastern Mau Forest are more on the eastern side than on the western side. This is because the conversion of forest land to cropland has occurred more on the eastern side than on the western side giving an indication of more pressure points on eastern side.

The area covered by different land cover types for 1986, 1995, 2003 and 2014 (Table 6) based on satellite imagery classification reveals the variation in magnitude of land cover change between land cover types (Fig. 9). Based on the aggregate land cover area change (the total change from a given land cover type to other land cover types) plantation forest changed by 19,007.91 ha, grassland by 7,227.54 ha, indigenous forest by $6,052.32$ ha, shrubland by 3,008.79 ha, cultivated fields by 57.96 ha, built up area by 11.97 ha and bare ground by 5.94 ha. The trend of land cover change in Eastern Mau Forest between 1986 and 2014 is different for different land cover types. Some land cover types increased in size in terms of area covered spatially while others decreased 
(Figs. 10, 11, 12, 13 and 14). Land cover classes that increased in size include cultivated fields and built up area. Those that decreased include indigenous forest, plantation forest, shrubland, grassland and bare ground. Some land cover types had a continuous increasing trend, others had a continuous decreasing trend while others had a trend of both increasing and decreasing. Cultivated fields had a continuous increasing trend between 1986 and 2014. Plantation forest, grassland and bare ground land cover types had a continuous decreasing trend. Indigenous forest increased from 1986 to 1995 then decreased from 1995 to 2014. Shrubs decreased from 1986 to 1995 , increased from 1995 to 2003 and then decreased from 2003 to 2014. Built up area decreased from 1986 to 1995 then increased from 1995 to 2014. The spatial coverage of built up area and bare ground in terms of size is insignificant as compared to other land cover types.

Table 6. Land cover classification between 1986 and 2014

\begin{tabular}{|c|c|c|c|c|c|c|c|c|}
\hline \multirow[t]{2}{*}{ Land Cover } & \multicolumn{2}{|c|}{1986} & \multicolumn{2}{|c|}{1995} & \multicolumn{2}{|c|}{2003} & \multicolumn{2}{|c|}{2014} \\
\hline & $\begin{array}{c}\text { Area in } \\
\mathrm{Ha}\end{array}$ & $\begin{array}{c}\% \% \\
\text { Coverage } \\
\end{array}$ & $\begin{array}{c}\text { Area in } \\
\text { Ha }\end{array}$ & $\begin{array}{c}\% \\
\text { Coverage } \\
\end{array}$ & $\begin{array}{c}\text { Area in } \\
\mathrm{Ha}\end{array}$ & $\begin{array}{c}\% \\
\text { Coverage } \\
\end{array}$ & $\begin{array}{c}\text { Area in } \\
\mathrm{Ha}\end{array}$ & $\begin{array}{c}\% \\
\text { Coverage } \\
\end{array}$ \\
\hline Grassland & 10742 & 16 & 9707 & 15 & 5796 & 9 & 5559 & 8 \\
\hline Shrubland & 3597 & 6 & 2392 & 4 & 2440 & 4 & & 2 \\
\hline $\begin{array}{l}\text { Plantation } \\
\text { forest }\end{array}$ & 22101 & 34 & 22079 & 33 & & 11 & 4652 & 7 \\
\hline $\begin{array}{l}\text { Indigenous } \\
\text { forest }\end{array}$ & 28579 & 43 & & 46 & 25331 & 38 & 23511 & 36 \\
\hline $\begin{array}{l}\text { Cultivated } \\
\text { fields }\end{array}$ & 845 & 1 & 1631 & 2 & 25070 & 38 & 30837 & 47 \\
\hline Built up area & & $<1$ & 14 & $<1$ & 34 & $<1$ & 73 & $<1$ \\
\hline Bare ground & 9 & $<1$ & 9 & $<1$ & 6 & $<1$ & 3 & $<1$ \\
\hline Total & 65889 & & 65889 & & 65889 & & & \\
\hline
\end{tabular}

\section{Land Cover Change (1986 - 2014)}

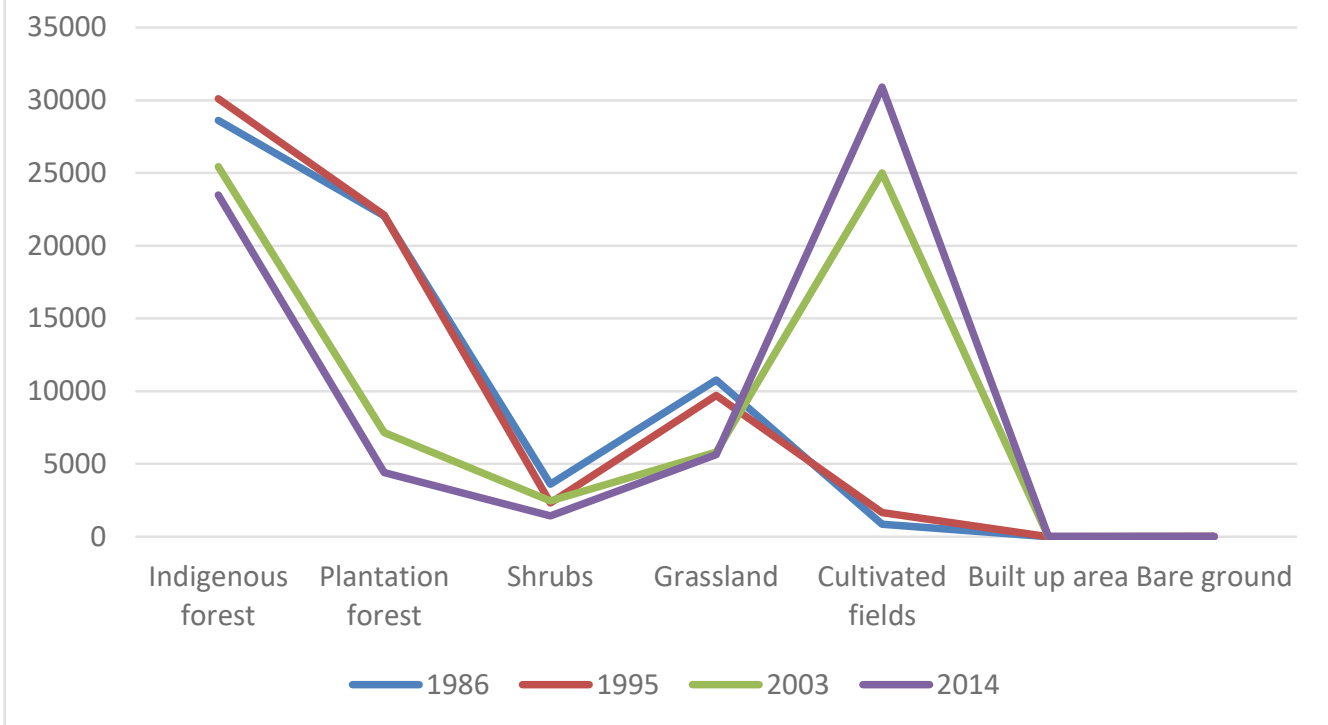

Figure 9. Variation of land cover change between 1986 and 2014 


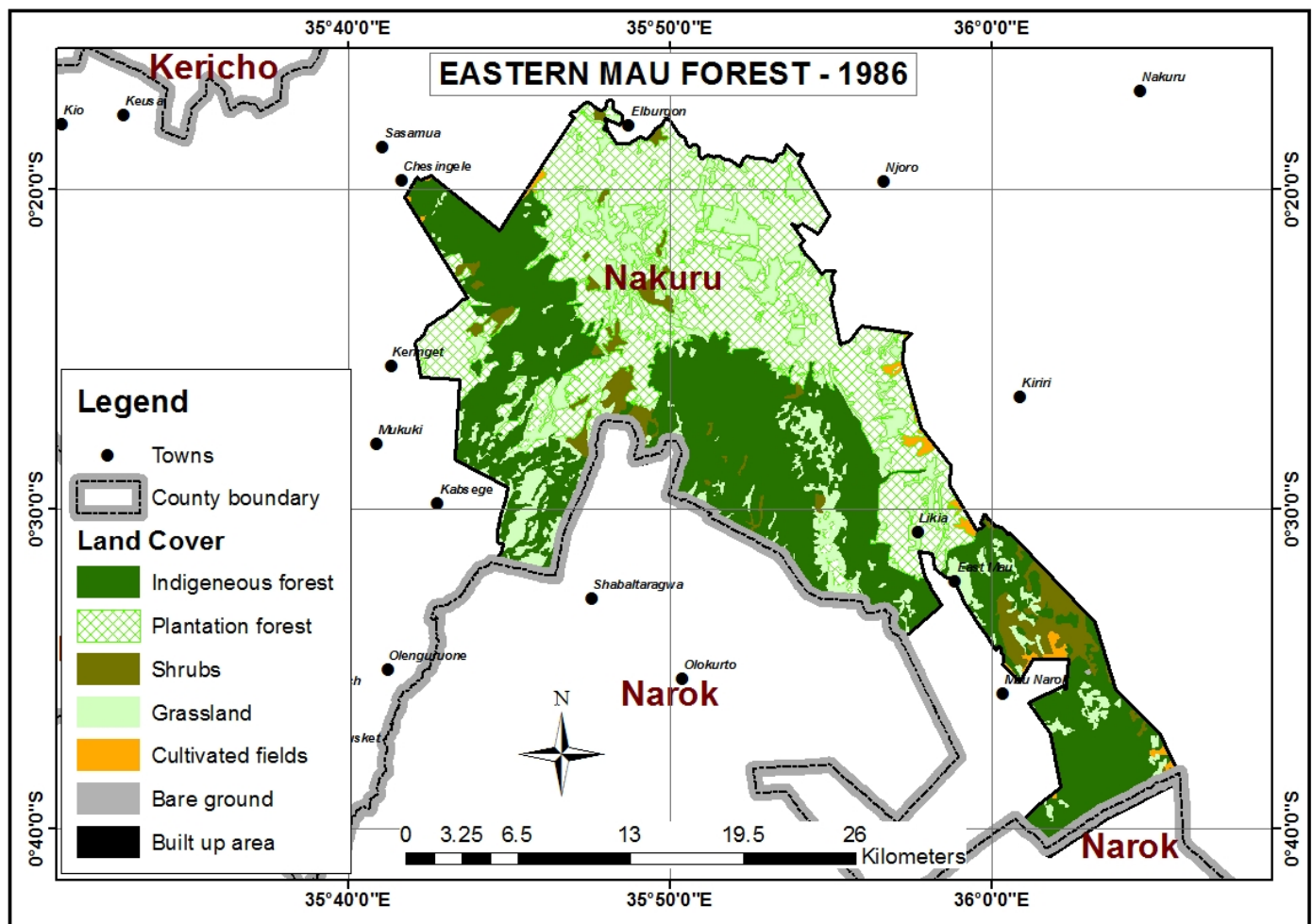

Figure 10. Classified land cover of 1986

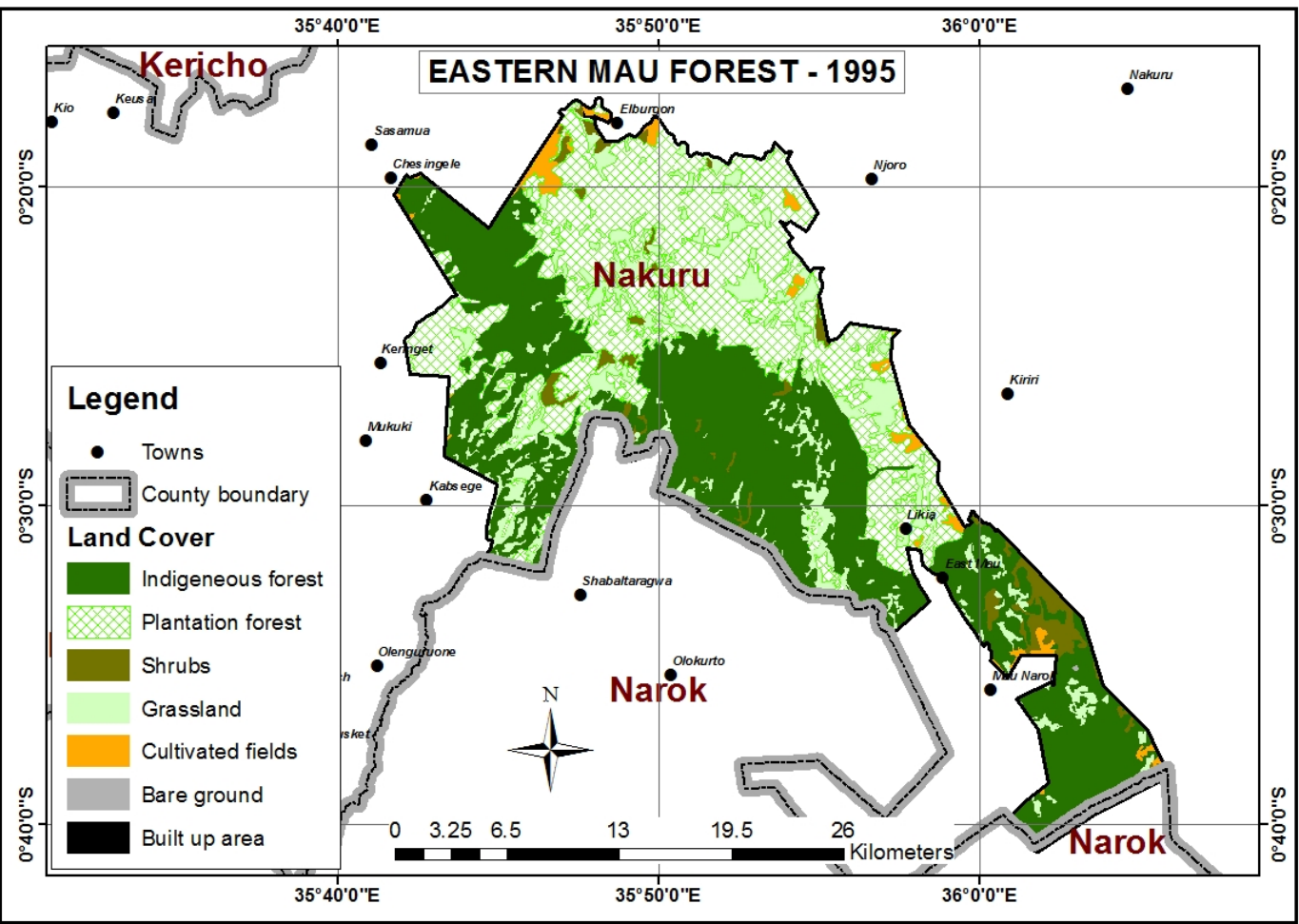

Figure 11. Classified land cover of 1995 


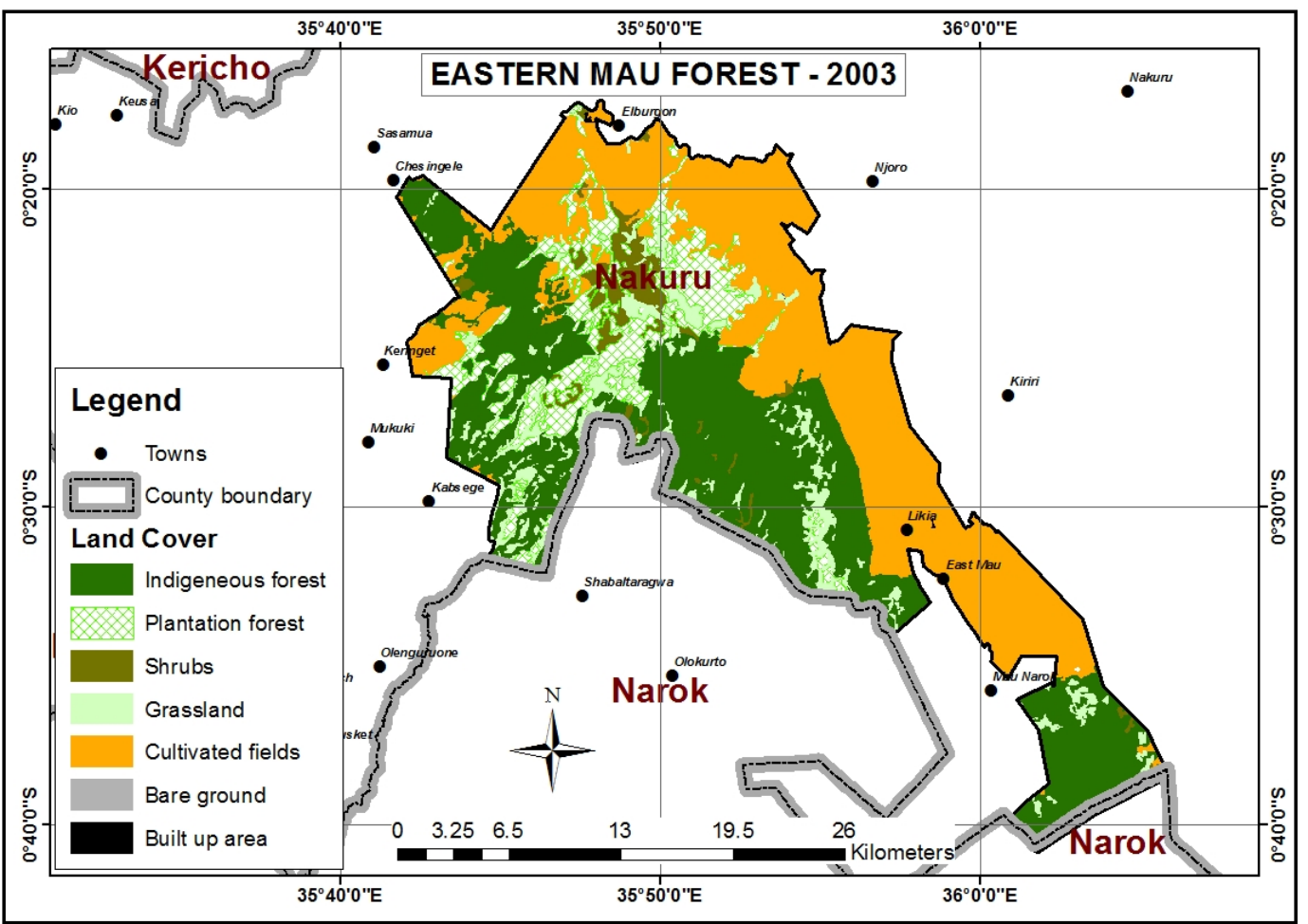

Figure 12. Classified land cover of 2003

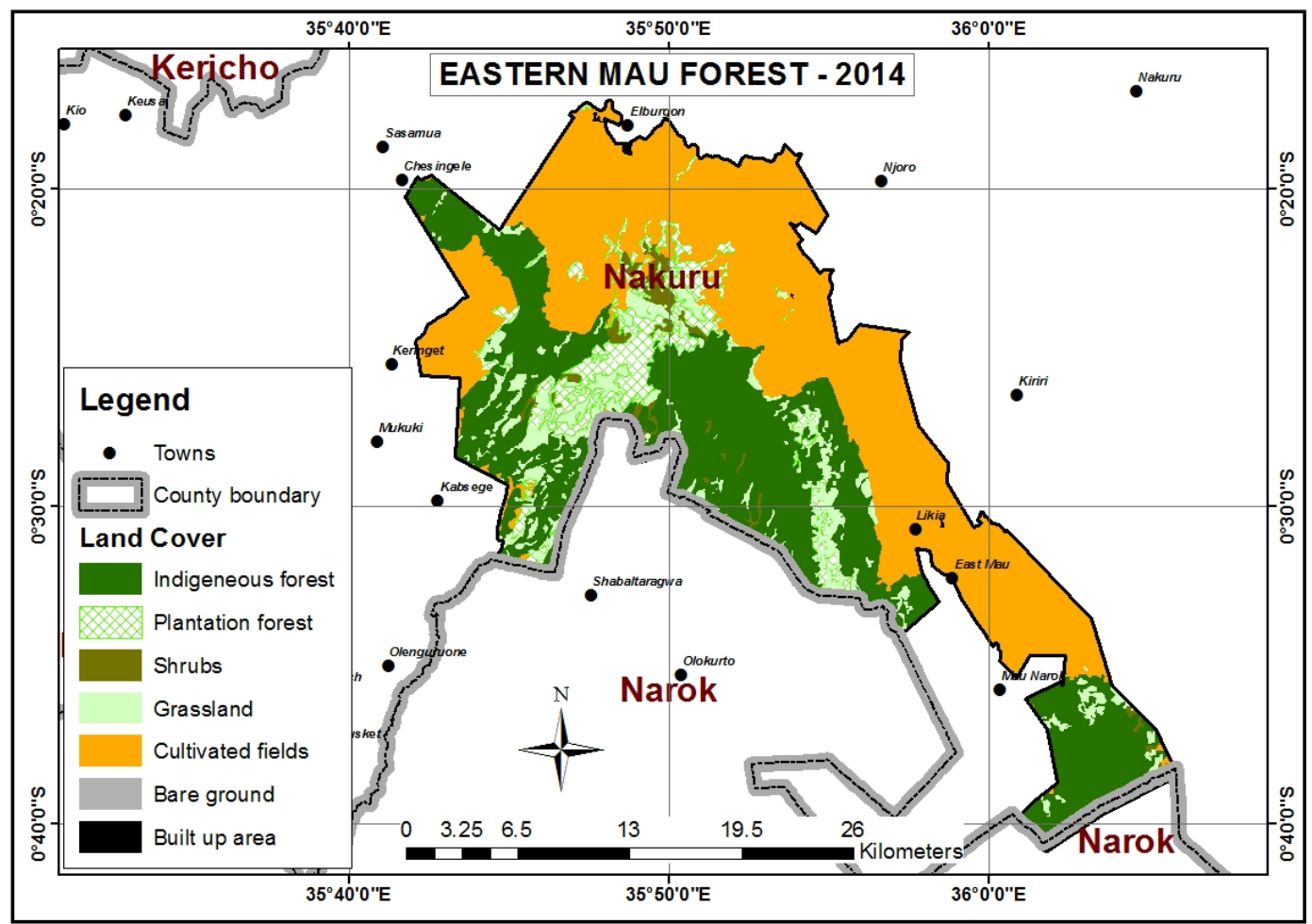

Figure 13. Classified land cover of 2014 


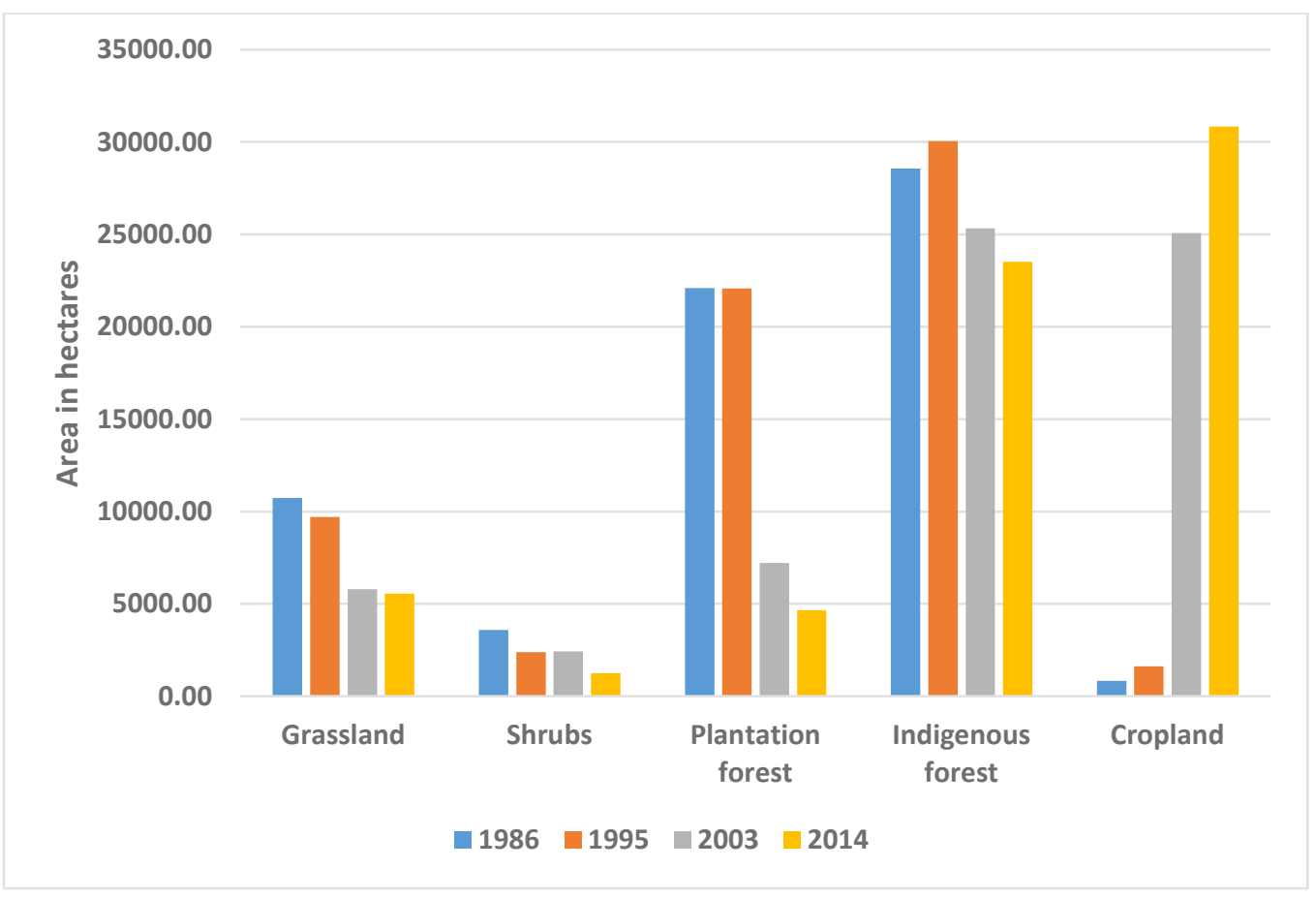

Figure 14. Land cover change trend (1986-2014)

Different drivers of land cover change in Eastern Mau Forest were identified. Those identified include cultivation of crops, construction of settlements, grazing of livestock, charcoal burning, firewood collection, logging, bee keeping and, medicinal herbs extraction. Eastern Mau Forest land cover classification and analysis had more intact indigenous forest on the western side than on the eastern side which was an indication of having more pressure points on the eastern side than on the western side. Increase in cropland as an activity that leads to land cover change was more on the eastern side than on the western side. Similarly, increase in built up area as another activity that leads to land cover change was more on the eastern side than on the western side, especially in the area outside the forest boundary. Cultivation of forest land increased over the years as a result of the government allowing people to cultivate forest land as well as illegal forest land cultivation and illegal selling of forest land that is converted to agricultural land. Settlements are increasingly put up by increasing population as well as the increasing nearby towns/shopping centres. These settlements have a big influence on the land cover change in Eastern Mau Forest.

Results from land cover analysis showed that parts of Eastern Mau Forest that are next to towns and shopping centres have a land cover type of cultivated fields and not indigenous forest (Fig. 14). Residents of these settlements rely on charcoal, firewood and timber from Eastern Mau Forest which encourages illegal charcoal burning, firewood collection and logging in the forest. Grazing is done both on site and off site where animals graze inside the forest and grass is cut and transferred to other places for feeding livestock respectively. This encourages burning of grass in the forest during dry season to enable regeneration of good pasture in the rainy seasons. The burning ends up destroying forest trees thereby causing forest degradation. This burning is accelerated by the fact that most of the locals are pastoralists like the Maasai who rely on livestock for their livelihood. Also, some communities who live next to the forest and see themselves to be getting less benefits from the forest resources are tempted to indulge in illegal forest resource extractions leading to land cover change. 


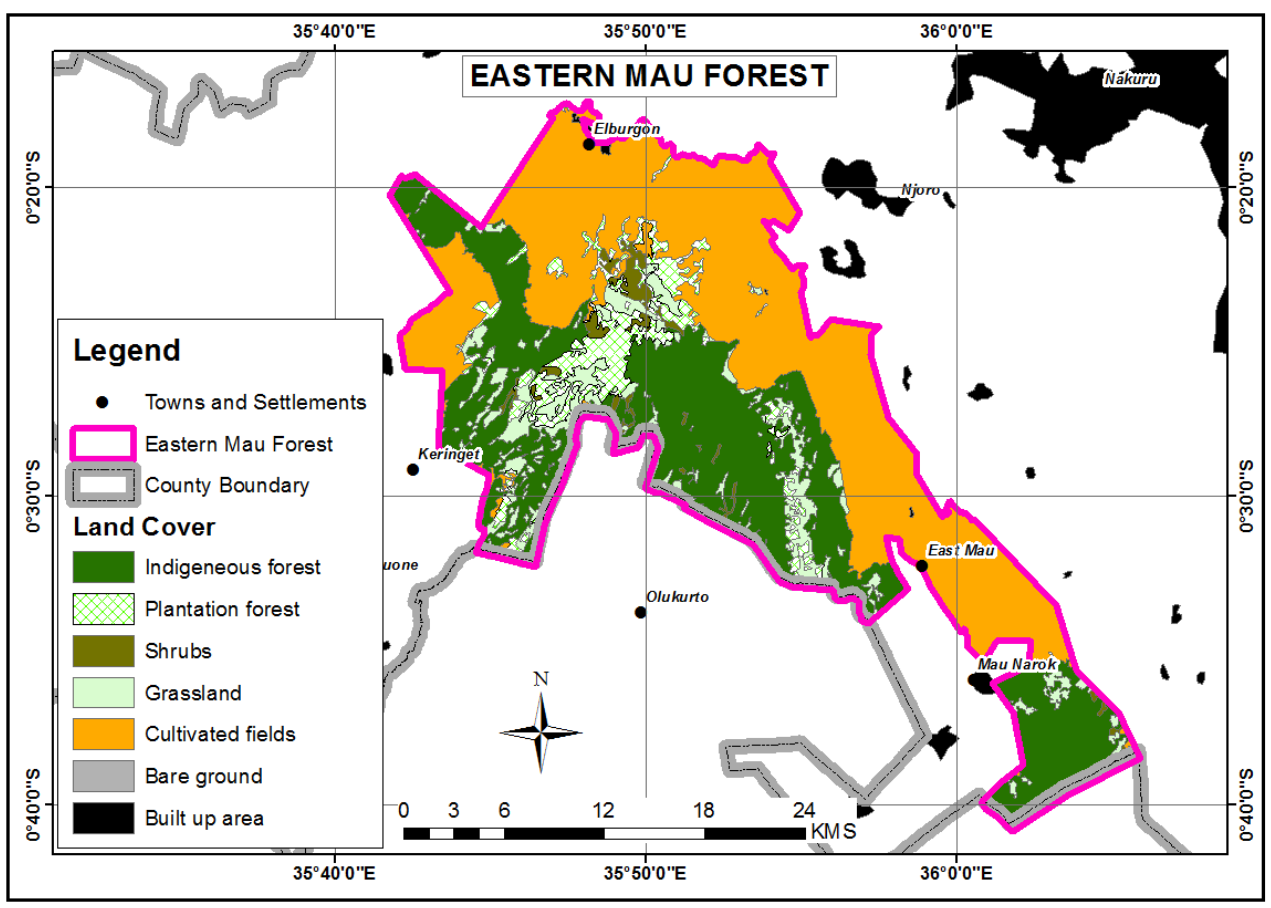

Figure 15. Cropland and settlements as main drivers of land cover change (Eastern side)

\subsection{Change Detection Results}

Change detection analysis was computed based on cross-tabulation analysis of areas of different land cover types of different years in IDRISI Selva software using Land Change Modeler tool. This analysis was carried out to show which land cover types had changed, to which other types and by how much hectares. The changes computed were those of 1986-1995, 1995-2003 and 2003-2014. The unchanged amount of specific land cover classes during specific periods are in the major diagonal of the matrix. (Tables 7, 8 and 9).

Table 7. Land cover change matrix for Eastern Mau Forest between 1986 and 1995

\begin{tabular}{|c|c|c|c|c|c|c|c|c|c|}
\hline \multirow[t]{10}{*}{1986} & \multicolumn{9}{|c|}{1995} \\
\hline & $\begin{array}{l}\text { Land } \\
\text { Cover } \\
\text { Class }\end{array}$ & Grassland & Shrubland & $\begin{array}{c}\text { Plantation } \\
\text { forest }\end{array}$ & $\begin{array}{l}\text { Indigenous } \\
\text { forest }\end{array}$ & $\begin{array}{l}\text { Cultivated } \\
\text { fields }\end{array}$ & $\begin{array}{l}\text { Built } \\
\text { up } \\
\text { area }\end{array}$ & $\begin{array}{c}\text { Bare } \\
\text { ground }\end{array}$ & $\begin{array}{c}\text { Total } \\
\text { Change } \\
\text { (Hectares) }\end{array}$ \\
\hline & Grassland & 7354.89 & 252.81 & 2406.06 & 605.61 & 124.29 & 1.26 & 0 & 10744.92 \\
\hline & Shrubland & 228.24 & 1637.19 & 630.90 & 1023.75 & 68.94 & 9.72 & 0 & 3598.74 \\
\hline & $\begin{array}{l}\text { Plantation } \\
\text { forest }\end{array}$ & 2067.12 & 466.65 & 18933.57 & 0.09 & 631.98 & 0.36 & 0 & 22099.77 \\
\hline & $\begin{array}{l}\text { Indigenous } \\
\text { forest }\end{array}$ & 35.10 & 17.91 & 108.54 & 28409.31 & 3.68 & 0 & 0 & 28574.54 \\
\hline & $\begin{array}{l}\text { Cultivated } \\
\text { fields }\end{array}$ & 20.16 & 0 & 5.58 & 15.30 & 802.62 & 0 & 0 & 843.66 \\
\hline & $\begin{array}{l}\text { Built up } \\
\text { area }\end{array}$ & 0 & 17.01 & 0 & 0 & 0 & 2.07 & 0 & 19.08 \\
\hline & $\begin{array}{l}\text { Bare } \\
\text { ground }\end{array}$ & 0 & 0 & 0 & 0 & 0 & 0 & 8.73 & 8.73 \\
\hline & $\begin{array}{l}\text { Total } \\
\text { Change } \\
\text { (Hectares) }\end{array}$ & 9705.51 & 2391.57 & 22084.65 & 30054.06 & 1631.51 & 13.41 & 8.73 & 65889.44 \\
\hline
\end{tabular}


Table 8. Land cover change matrix for Eastern Mau Forest between 1995 and 2003

\begin{tabular}{|c|c|c|c|c|c|c|c|c|c|}
\hline \multirow[t]{10}{*}{1995} & \multicolumn{9}{|c|}{2003} \\
\hline & $\begin{array}{l}\text { Land } \\
\text { Cover } \\
\text { Class }\end{array}$ & Grassland & Shrubland & $\begin{array}{l}\text { Plantation } \\
\text { forest }\end{array}$ & $\begin{array}{c}\text { Indigenous } \\
\text { forest }\end{array}$ & $\begin{array}{l}\text { Cultivated } \\
\text { fields }\end{array}$ & $\begin{array}{l}\text { Built } \\
\text { up } \\
\text { area }\end{array}$ & $\begin{array}{l}\text { Bare } \\
\text { ground }\end{array}$ & $\begin{array}{c}\text { Total } \\
\text { Change } \\
\text { (Hectares) }\end{array}$ \\
\hline & Grassland & 4801.00 & 696.78 & 500.85 & 130.68 & 3562.02 & 13.23 & 0 & 9704.56 \\
\hline & Shrubland & 34.83 & 578.52 & 268.38 & 17.82 & 1488.96 & 3.06 & 0 & 2391.57 \\
\hline & $\begin{array}{l}\text { Plantation } \\
\text { forest }\end{array}$ & 780.21 & 1073.25 & 6444.81 & 190.89 & 13593.33 & 2.16 & 0 & 22084.65 \\
\hline & $\begin{array}{l}\text { Indigenous } \\
\text { forest }\end{array}$ & 127.26 & 65.70 & 2.07 & 24987.96 & 4870.75 & 0 & 1.71 & 30055.45 \\
\hline & $\begin{array}{l}\text { Cultivated } \\
\text { fields }\end{array}$ & 54.90 & 23.49 & 0 & 0 & 1547.10 & 5.58 & 0 & 1631.07 \\
\hline & $\begin{array}{l}\text { Built up } \\
\text { area }\end{array}$ & 0 & 0 & 0 & 0 & 2.97 & 10.44 & 0 & 13.41 \\
\hline & $\begin{array}{l}\text { Bare } \\
\text { ground }\end{array}$ & 0 & 0 & 0 & 0 & 5.13 & 0 & 3.60 & 8.73 \\
\hline & $\begin{array}{l}\text { Total } \\
\text { Change } \\
\text { (Hectares) }\end{array}$ & 5798.20 & 2437.74 & 7216.11 & 25327.35 & 25070.26 & 34.47 & 5.31 & 65889.44 \\
\hline
\end{tabular}

Table 9. Land cover change matrix for Eastern Mau Forest between 2003 and 2014

\begin{tabular}{|l|l|r|r|r|r|r|r|r|r|}
\hline $\mathbf{2 0 0 3}$ & \multicolumn{9}{|c|}{$\mathbf{2 0 1 4}$} \\
\cline { 2 - 10 } & $\begin{array}{l}\text { Land } \\
\text { Cover } \\
\text { Class }\end{array}$ & Grassland & Shrubland & $\begin{array}{l}\text { Plantation } \\
\text { forest }\end{array}$ & $\begin{array}{l}\text { Indigenous } \\
\text { forest }\end{array}$ & $\begin{array}{l}\text { Cultivated } \\
\text { fields }\end{array}$ & $\begin{array}{l}\text { Built } \\
\text { up } \\
\text { area }\end{array}$ & $\begin{array}{l}\text { Bare } \\
\text { ground }\end{array}$ & $\begin{array}{l}\text { Total } \\
\text { Change } \\
\text { (Hectares) }\end{array}$ \\
\hline Grassland & $\mathbf{4 0 4 4 . 6 9}$ & 101.07 & 360.09 & 277.47 & 1014.66 & 1.17 & 0 & 5799.15 \\
\hline Shrubland & 94.86 & $\mathbf{1 0 8 5 . 5 8}$ & 294.03 & 2.07 & 961.20 & 0 & 0 & 2437.74 \\
\hline $\begin{array}{l}\text { Plantation } \\
\text { forest }\end{array}$ & 746.01 & 44.82 & $\mathbf{3 3 7 5 . 6 3}$ & 262.71 & 2786.94 & 0 & 0 & 7216.11 \\
\hline $\begin{array}{l}\text { Indigenous } \\
\text { forest }\end{array}$ & 486.09 & 0 & 508.95 & $\mathbf{2 2 8 4 9 . 8 3}$ & 1482.92 & 0 & 0 & 25327.79 \\
\hline $\begin{array}{l}\text { Cultivated } \\
\text { fields }\end{array}$ & 187.11 & 22.50 & 109.08 & 119.34 & $\mathbf{2 4 5 9 2 . 4 1}$ & 37.71 & 0.72 & 25068.87 \\
\hline $\begin{array}{l}\text { Built up } \\
\text { area }\end{array}$ & 0 & 0 & 0 & 0 & 0 & $\mathbf{3 4 . 4 7}$ & 0 & 34.47 \\
\hline $\begin{array}{l}\text { Bare } \\
\text { ground }\end{array}$ & 0 & 0 & 0 & & 0 & 2.97 & 0 & $\mathbf{2 . 3 4}$ & 5.31 \\
\hline $\begin{array}{l}\text { Total } \\
\text { Change } \\
\text { (Hectares) }\end{array}$ & $\mathbf{5 5 5 8 . 7 6}$ & $\mathbf{1 2 5 3 . 9 7}$ & $\mathbf{4 6 4 7 . 7 8}$ & $\mathbf{2 3 5 1 1 . 4 2}$ & $\mathbf{3 0 8 4 1 . 1 0}$ & $\mathbf{7 3 . 3 5}$ & $\mathbf{3 . 0 6}$ & $\mathbf{6 5 8 8 9 . 4 4}$ \\
\hline
\end{tabular}

\section{Conclusions and Recommendations}

Land cover in Eastern Mau Forest was changing in a way that some land cover types were increasing in spatial coverage while others were decreasing especially on the eastern side of the study area. This gives an indication of where to find pressure points for land cover change. It was likely that some decreasing land cover types will disappear if the expansion of the increasing types was not checked. Cropland and built up area expansions were the main drivers for land cover change in Eastern Mau Forest area. This was especially for decline of indigenous and plantation forest land cover types. Sustainable use of forest resources in Eastern Mau Forest area would only be possible if expansion of drivers of land cover change in Eastern Mau Forest area were checked or reduced. The study provided the following recommendations based on the conclusions made:

1. On the land cover change that was observed in Eastern Mau Forest the study recommended that: 
i. Resettlement activities be reduced or eliminated in the Eastern Mau Forest area in order to reduce or stop cropland expansion. The authority concerned must come up with a policy that should end resettling people on forest land and prohibit settlements at the forest boundaries.

ii. There is need to carry out continuous studies on land cover change in Eastern Mau Forest as a way of ensuring that up to date information on the changes that are taking place is made available to the relevant authorities for the necessary mitigation measures.

2. On the drivers of land cover change that were identified in Eastern Mau Forest the study recommended that:

i. Excision of forest land for crop cultivation should not be encouraged. There is need to have a policy that prohibits providing environmentally fragile lands including forest land for production of more food.

ii. It is important to invest in studies that will provide a chance to local people who stay in forests participate in finding ways on how to use forest resources sustainably. This is especially to communities like Ogieks who are known to have always stayed in forests.

3. On the sustainable use of forest resources in Eastern Mau Forest the study recommended that:

i. There is need to formulate policies that will create a buffer zone of sustainable plantation forest activities in Eastern Mau Forest and the adjacent areas as a measure against unchecked cropland expansion.

i. Scientific research should be carried out on the environmental suitability of the exotic species to be used in the sustainable plantation forest buffer zone before introducing them to avoid interfering with the original state of the environment like in cases where some lower herbaceous plants disappear after the introduction of exotic species.

\section{Conflict of Interest}

The author declares that there is no conflict of interest.

\section{Acknowledgements}

The author greatly appreciates the financial support provided by the STAKE Project that is a cooperation between the Wangari Maathai Institute of Peace and Environmental Studies, the Green Belt Movement, Kenya Forest Research Institute and the University of Copenhagen, Denmark. It was because of this funding that a successful fieldwork was carried out to validate satellite image classification and collect data on forest resource use and drivers of land cover change for analysis.

\section{References}

[1] KFWG, Kenya Forests Working Group. Excision and settlement in the Mau Forest. Kenya Forest Working Group report, Nairobi, Kenya, 2001.

[2] FAO, Food and Agriculture Organization of the United Nations. State of the World's Forests (FAO), Viale delle Terme di Caracalla, 00153 Rome, Italy, 2012.

[3] M. Tiffen, M. Mortimore, F. Gichuki, More people, less erosion: environmental recovery in Kenya, ODI, London, UK, 1994.

[4] KFMP, Kenya Forestry Master Plan Project, Kenya Forestry Master Plan Development Programmes, 1994. 
[5] Adoyo et al., Kenya Political, Social and Environmental Issues, Nova Science Publishers, Inc., 2012.

[6] M.A. Quaddus, M.A.B. Siddique, Modelling sustainable development planning: a multicriteria decision conferencing approach. Environment International. 27(2-3) (2001) 8995.

[7] J.K. Maingi, S.E. Marsh, Assessment of environmental impacts of river basin development on the riverine forests of eastern Kenya using multi-temporal satellite data. Arizona Remote Sensing Center, University of Arizona, Tucson, Arizona 85750, USA, 2001.

[8] BirdLife International, Important Bird Areas factsheet: Mau forest complex, 2015.

[9] GoK, Report of the Government's Task Force on the Conservation of the Mau Forests Complex, 2009.

[10] UNEP, How Much Forest Cover in Kenya? A surprisingly difficult question to answer. United Nations Environment Programme, 2012.

[11] W.G. Sombroek, H.M.H. Braun, B.J.A. van der Pouw, The explanatory soil map and agroclimatic zone map of Kenya. Report No. E. 1, Kenya Soil Survey, Nairobi, Kenya, 1980.

[12] L.O. Olang, P. Kundu, Land Degradation of the Mau forest complex in Eastern Africa. a review for management and restoration planning, in: Environmental Monitoring, 2011.

[13] C. Burnett, T. Blaschke, A multi-scale segmentation/object relationship modelling methodology for landscape analysis, Ecological Modelling. 168 (2003) 233-249.

[14] J. Jenness, J.J. Wynne, Cohen's Kappa and classification table metrics 2.0: An ArcView 3.x extension for accuracy assessment of spatially explicit models. Open-File Report OF 20051363. Flagstaff, AZ: US Geological Survey, Southwest Biological Science Center, 2005. 